\title{
1. Introduction: the debate on corporate embeddedness
}

\section{Martin Heidenreich}

Some time ago, my students and I visited the divisional headquarters (HQ) of a multinational company (MNC) to find out how it organized its innovation processes. One of the company's representatives explained that it operates in most countries of the world, that two-thirds of its staff are employed abroad and that its research facilities are spread all over the world. He emphasized the strength of these foreign research and development (R\&D) sites, the high technological competences of its employees, and the public support for and generally positive attitude to innovation in many foreign countries. In a publication, the company stressed the necessity 'to think and act internationally' because 'the significance of national economies is declining'. We were deeply impressed because obviously the company was able to make full use of the advantages of a global economy without any problems. However, the representative then explained how the innovation process was organized for one of the most successful product lines of his division and this proved to be much less internationally structured than anticipated. Most of the R\&D for that product line still took place about ten miles away from the divisional HQ - close to its central production site and close to many important internal and external suppliers. Only in the last decade was a Chinese R\&D unit set up for a product designated especially for the Chinese market and which took into account the specific budget constraints and requirements of developing countries. Even though the technological core competences of the division were still concentrated close to its HQ, six years after its foundation the foreign R\&D site had developed sufficient competences to assume a leading role in the development of a new product (although crucial decisions were still taken in the home country of the MNC). This R\&D site also appeared to be much less globally organized than anticipated, as its major advantage was its local embeddedness in a publicly supported hightech cluster also accommodating public R\&D facilities, production, training, regulatory agencies, important pilot clients and the R\&D facilities of two of its globally most important competitors. 
This example shows that MNCs are crucial actors in a global knowledgebased economy. They are able to 'transfer' knowledge across national borders without sacrificing the advantages of inner-organizational coordination (Dunning and Lundan, 2008). However, our example also illustrates that these companies are not territorially disembedded, footloose organizations that are only able to transfer knowledge across borders. They are also important arenas for the creation of knowledge, especially by combining the advantages of inner-organizationally coordinated crossborder production and innovation strategies with the advantages of local proximity and the use of specific regional and national factors (Bartlett and Ghoshal, 1989; Sölvell and Birkinshaw, 2007). The R\&D units of the company we visited were regionally embedded in both its home country and its host country. These external contexts were important bases for the global innovativeness and competiveness of the company. Therefore our example (and other, more systematic evidence on the 'non-globalization' of innovation; cf. Patel and Pavitt, 1991 and Heidenreich et al., 2010) questions the assumption that MNCs are footloose companies operating in a globally interlinked economy (Ohmae, 1990). On the contrary, instead of being footloose, they more resemble a millipede whose subsidiaries represent multiple feet in different regional and national arenas.

A major advantage of the regional and national embeddedness of MNCs is that they may facilitate learning processes with companies in the proximity (customers, competitors, suppliers and service providers). In addition to inner-organizational forms of learning and knowledge exchange between HQ and subsidiaries, MNCs can thus rely on external competences. These external learning processes are supported by institutions that shape the cooperation between heterogeneous actors and that provide collective competition goods, for example qualified employees, basic research, advanced technological competences, consensual relations with employees or network brokers (Meyer et al., 2011). This institutional environment also shapes the technological competences and market positions of subsidiaries (Andersson et al., 2002, 2007). At the core of corporate innovation strategies is thus the ability of internationally distributed organizations to combine two different forms of learning: first, organizational learning within and beyond national boundaries; second, institutionally stabilized learning with external partners, usually within the same national or even regional context. MNCs thus translate the relationship between globalization and regionalization that is characteristic of a globalized economy (Giddens, 1990; Held et al., 1999) into an organizational challenge: the challenge of combining inner-organizational and institutionally embedded learning with external partners (Phene and Almeida, 2008; Heidenreich et al., 2012). 
The question is how MNCs can combine the advantages of internationally distributed innovation processes with nationally and regionally embedded competences and know-how. How can the observed internationalization of companies be reconciled with the crucial role of different domestic locations and competences? To answer this question, in the following we shall briefly review four different academic debates. First, we shall review selected aspects of the debate on embeddedness in order to avoid the traps of over- or underestimating the determining role of societal environments on companies (section 1.1). Second, the debate on national systems of production and innovation conceptualizes the context of organizations as (mostly formal) institutions that contribute to the solution of the uncertainties of innovation processes and the coordination problems faced by companies in relation to their stakeholders (section 1.2). Third, in addition to institutions, regional studies highlight two other aspects of corporate embeddedness: the role of inter-organizational networks and the role of informal rules that are often the result of the social, organizational and cognitive proximity of regional actors (section 1.3). Fourth, similar to regional studies, international business studies also highlight the essential role of business networks in the embeddedness of MNCs and their subsidiaries. They additionally stress the role of institutions and (mostly national) political decisions (section 1.4). On the basis of these approaches we are able to propose an understanding of corporate embeddedness that takes into account crucial results of these four, largely unrelated, debates (section 1.5). Finally, we shall present the contributions in this volume that highlight three different dimensions of this embeddedness: the dilemmatic nature, the essential role of 'knowledge infrastructures', that is, organizational and institutional conditions essential for corporate innovation processes, and the cultural and political environment of MNCs (section 1.6).

\subsection{STRUCTURAL AND RELATIONAL CONCEPTS OF EMBEDDEDNESS}

A starting point for the debate on the societal context of organizations is that institutions, that is, 'the humanly devised constraints that structure political, economic and social interaction' (North, 1991: 97), shape the behaviour and the strategies of economic actors. Faced with the uncertainties of economic life and the manifold coordination problems associated with innovation processes, companies tend to turn to established rules, practices and social norms for guidance and orientation. The concept of institutions is very broad and comprises formal institutions, for example 
legal ones, and informal institutions, which are often designated as cultures and traditions of a specific community.

In neo-institutional approaches their role is often analysed as a sort of inescapable isomorphic pressure to which a company has to defer in order to gain legitimacy. Such institutional determinism can be avoided by the embeddedness concept that was initially proposed by Karl Polanyi in the 1940s. He proposed the concept of embeddedness in order to distinguish traditional, institutionally embedded societies from modern, disembedded market societies. He summarizes his discussion of the social conditions for the emergence of a relatively autonomous economic sphere in the nineteenth century as follows: 'Instead of economy being embedded in social relations, social relations are embedded in the economic system' (Polanyi, 1944: 57). His macrosociological or structural notion of embeddedness has become an essential cornerstone of economic sociology in criticizing the neoclassical assumptions of atomistic, self-interested economic actors (Krippner and Alvarez, 2007). In contrast to Polanyi, Granovetter (1985: 504) proposed a less structural and more relational understanding of embeddedness. He uses this concept to highlight the social dimensions of economic action and assumes that economic 'behavior is closely embedded in networks of interpersonal relations'. In contrast to an 'oversocialized approach of generalized morality' and an 'undersocialized one of impersonal, institutional arrangements', he proposes a dynamic, process- and experience-based approach to trust and order that focuses both on pre-existing structures (or 'networks') and on the direct experiences of competent, knowledgeable social actors: 'Better than the statement that someone is socially known to be reliable is information from a trusted informant that he has dealt with that individual and found him so. Even better is information from one's own past dealings with that person' (Granovetter, 1985: 490).

Beckert (2003: 769) combines the structural and the relational notions of embeddedness in the following definition: 'Embeddedness refers to the social, cultural, political, and cognitive structuration of decisions in economic contexts. It points to the indissoluble connection of the actor with his or her social surrounding.' This definition, which we adopt in this chapter, reflects the crucial insight of the structuration theory by focusing on the important role of individual or collective actors (e.g. companies) in the reproduction of social structures (Giddens, 1990). Embeddedness therefore is not merely an external or contextual determinant of organizational strategies; it is also the result of organizational strategies: MNCs also shape strategically their institutional environment (cf. Hancké, Chapter 12 in this volume; Cantwell et al., 2010).

In a dynamic perspective, the mutual shaping of companies and their societal environments can also be analysed as 'co-evolution' (Nelson, 
1994). The concept of co-evolution offers a conceptual framework for analysing the recursive reproduction of entrepreneurial strategies and their institutional environment in a more dynamic way than concepts that focus only on isomorphic pressures, the search for organizational legitimacy or path dependencies.

A major insight provided by the debate on embeddedness is that an $\mathrm{MNC}$ is not only linked to its multiple environments by personal relations, networks and non-economic motives as a 'Granovetterian' interpretation of the conception of embeddedness would suggest, but by social institutions that are a crucial factor in corporate embeddedness. These institutions systematically shape the perception of organizational challenges, of the best or most appropriate organizational strategies and the available resources. They are dynamically reproduced by skilled social actors (Fligstein, 2001), for example MNCs. In this volume Heidenreich and Mattes (Chapter 2) as well as Rehfeld (Chapter 10) show that corporate embeddedness is not a quasi-natural, taken-for-granted phenomenon but often an explicit, strategic choice.

\subsection{EMBEDDEDNESS VIA NATIONAL INSTITUTIONS}

National institutions are especially important for the embeddedness of companies in their societal context. In the following we shall discuss four approaches that focus on national institutions and their role in entrepreneurial structures and strategies. In this way we want to show how the role of institutions is conceptualized in the coordination of economic action and the choice of organizational innovation strategies. These four approaches are the 'social systems of production approach' (Hollingsworth and Boyer, 1997), the 'varieties of capitalism approach' (Hall and Soskice, 2001), the 'business systems approach' (Whitley, 1999) and the 'national systems of innovation approach' (Lundvall, 1992; Edquist, 2005).

The starting point of the 'social systems of production approach' (SSP) is that the emergence and stability of national production models, for example the diversified quality production in Germany (Streeck, 1991), lean production in Japan (Womack et al., 1990), modular production networks in the USA (Sturgeon, 2002) or flexible specialization in Italy (Zeitlin, 2008), depend on specific institutional configurations that provide the habits, the taken-for-granted accounts, the rules and the resources required for the stabilization of the country-specific product, management and organizational models. Diversified quality production for example requires a public system of vocational training and strong trade unions 
in order to provide skilled workers. Otherwise hire-and-fire policies and labour poaching would undermine the stability of internal labour markets, which form the basis for high-quality products as the 'societal effects' approach already demonstrated in the 1980s (Maurice et al., 1986). The SSP approach assumes that national institutions are essential for the coordination of economic activities between companies and their employees, their shareholders, their banks, their customers and suppliers, schools, politics and the broader public: '[T] he choices of coordinating mechanisms ... are constrained by the social context within which they are embedded' (Hollingsworth and Boyer, 1997: 11). A social system of production is characterized by 'institutional complementarities' between its different components $^{1}$ - an assumption that also explains the strong and stable concentration of MNCs in the core European regions (cf. Koschatzky and Baier, Chapter 9 in this volume).

This assumption is also fundamental for the "varieties of capitalism approach' (Hall and Soskice, 2001; Hancké et al., 2007). In contrast to the SSP, however, which allows for multiple and heterogeneous national production models, the varieties of capitalism approach ( $\mathrm{VoC})$ distinguishes only two basic models: coordinated and liberal market economies. These types are characterized by either a high or a low degree of coordination between the actors at the core of the different institutions (e.g. between employers and employees in the industrial relations system; Hall and Gingerich, 2009). Similar to the SSP approach, these two types of market economies are interpreted as complex configurations of different, mutually reinforcing institutions (especially the education and training system, the industrial relations system, the patterns of corporate governance and intercompany relations). The coordinated type of market economies is characterized by institutionally embedded forms of production (e.g. in Germany and Japan), while the liberal type is described as a disembedded economy with only very weak and arm's-length forms of coordination between companies and their societal environments (for example in the USA). The VoC approach places the firm and its ways of dealing with major coordination problems at the centre of its interest. It insists on the fact that 'institutions cannot be taken for granted but must be reinforced by the active endeavors of the participants' (Hall and Soskice, 2001: 17) Hancké (Chapter 12 in this volume), for example, shows that MNCs play a decisive role in shaping their institutional environment when their subsidiaries contribute to stronger collaboration between major companies in a region as a prerequisite for an industry-wide training system.

Whitley (1999: 34) defines national business systems as 'systems of economic coordination and control'. National business systems vary especially in three dimensions: in the governance dimension (i.e. the 
relationships between owners and controllers of economic resources); in the collaborative dimension (i.e. the coordination within production chains and industrial sectors and between competitors); and in the employment dimension, which refers to the relationship between employers and employees and the delegation of authority to employees. Different institutional contexts are distinguished according to the following institutional dimensions: dominant, risk-sharing state; strong intermediary associations; strong market regulation; capital market financial system or credit-based financial system; strong collaborative public training system; strong unions; centralized bargaining; low trust in formal institutions; paternalist authority relations; communal formal authority (cf. Whitley, 2002). In contrast to the aforementioned approaches, Whitley also takes into account informal, cultural dimensions of labour and management. In this volume, Barmeyer and Krüth (Chapter 11) as well as Rehfeld (Chapter 10) demonstrate that these informal institutions are an important element of the organizational environment. They shape the possibilities of public network policies (e.g. the French cluster policy focusing on pôles de compétitivité) and they also shape corporate globalization strategies.

In contrast to the previously discussed concepts, 'systems of innovation approaches' focus on the ability of a country, region or industrial sector to generate and recombine scientific and technical knowledge and to create new products or processes on this basis. Essential factors here are national, regional or sectoral institutions that reduce the uncertainties linked to innovations and facilitate the recombination of knowledge. A system of innovations has therefore been defined as a 'set of distinct institutions which jointly and individually contribute to the development and diffusion of new technologies ... it is a system of interconnected institutions to create, store and transfer the knowledge, skills and artefacts which define new technologies' (Metcalfe, 1995: 462-3). Lundvall (1992) focuses on the crucial role of socially embedded interactive learning processes between heterogeneous actors and distinguishes between narrowly and broadly defined concepts of national innovation systems. While the former embraces only R\&D organizations and institutions, a broader definition of national innovation systems 'includes all parts and aspects of the economic structure and the institutional set-up affecting learning as well as searching and exploring - the production system, the marketing system and the system of finance'. Despite the remaining methodological weaknesses of the systems of innovation approaches (Edquist, 2005), they stress the role of institutions in organizational learning processes. However, it remains unclear how these institutions exactly shape innovation processes within companies and which institutions really 'influence the development, diffusion, and use of innovations' (Edquist, 2005: 200). 
One conclusion that can be drawn from this discussion of these four approaches focusing on the national embeddedness of companies is that these institutions contribute to reducing uncertainties and solving organizational coordination problems. Institutions shape the relationships between companies, their own employees, employer associations, unions, schools, capital owners, competitors, suppliers and customers. In addition they provide crucial resources such as skilled employees and innovative competences. In this way they contribute towards solving collective-goods problems because private investments in R\&D or in the education and training of employees are in general not sufficient (due to free-rider problems).

A limitation of these approaches, especially for the debate on embedded MNCs, is that companies are conceived as rule takers that play according to the national rules of the game and do not function as rule makers. Their active involvement in the definition of these rules as well as the choice and the tensions between different national sets of rules are ignored. It is also assumed that companies are bound to only one set of rules: the rules of the respective national system. Both the possibility of transferring these rules to other national environments through the internationalization strategies of domestic MNCs (e.g. to Eastern European countries; cf. Narula and Guimón as well as Hancké, Chapters 12 and 13 in this volume) and the question of how international organizations deal with multiple institutional environments are ignored (cf. Kostova et al., 2008; Meyer et al., 2011). The debate on corporate embeddedness thus has to begin with national institutions and should take into account their functions (coordination, reduction of uncertainty, provision of resources and facilitation of interactive learning) as well as their relative stability and the institutional complementarities between them. However, the debate does not stop there.

\subsection{EMBEDDEDNESS IN REGIONAL NETWORKS AND INSTITUTIONS}

Not only nations but also regions are important environments for MNCs (Cooke et al., 2011; Iammarino et al., Chapter 7 in this volume). Similar to the national institutions, regional institutions also contribute to the private or public provision of products, services and qualifications (Le Galès and Voelzkow, 2001) and facilitate and stabilize cooperation, mutual exchange of knowledge and trust relationships, which might lead also to lock-in effects (Grabher, 1993). However, the advantages of regional economies are not only based on institutions but also on regional clusters and networks. These networks are a prerequisite for inter-organizational learning 
due to the spatial and social proximity of regionally concentrated companies; they facilitate the exchange of implicit, experience-based, uncodified knowledge and the recombination of previous knowledge (Boschma, 2005 and Asheim et al., Chapter 4 in this volume).

In early studies the advantages of regional proximity were analysed as a result of transaction cost advantages (Krugman, 1991). Other studies explain regional advantages by the possibility to exploit the experience, knowledge and skills of proximate companies. Taking the example of the textile industry in Lancashire in the nineteenth century, Marshall (1982: 225) described these learning and network effects: 'The mysteries of the trade become no mystery, but are as it were in the air'. Porter (1998) systematizes this intuition by explaining the competitive advantages of regionally concentrated clusters through their proximity to competitors and challenging clients, efficient regional suppliers and service providers and the availability of a qualified workforce. In this perspective regional advantages are not only the result of transaction cost savings but are also the result of mutual learning facilitated by geographic proximity, that is, by network effects (cf. also Cooke, Chapter 5 in this volume).

As early as the 1980s Piore and Sabel (1984) drew attention to the institutional bases of regional learning and innovation, which in the case of the Central Italian industrial districts they mostly conceive as stable communities and personal, direct, trust-based interactions. Storper (1997) proposes a less Granovetterian concept of regional embeddedness. He analyses regional economic relations as conversation and coordination, pointing to the crucial role of 'untraded interdependencies', that is, nonmarket relations, conventions, informal rules and habits that coordinate an economy faced with uncertainty. Regions are 'worlds of production' characterized by 'taken-for-granted mutually coherent expectations, routines, and practices, which are sometimes manifested as formal institutions and rules, but often not' (Storper, 1997: 38). These regional institutional orders shape the 'action capacities' of economic agents and the economic identities of territories and regions.

In comparison with the 'relational perspective' of Storper and similar (but largely independently) to the concept of national innovation systems (Edquist, 2005), the concept of 'regional innovation systems' (RIS) more strongly emphasizes the role of formal regional institutions (Cooke et al., 2004): an RIS consists of

firms in the main industrial cluster in a region including their support industries. Secondly, an institutional infrastructure must be present, i.e., research and higher education institutes, technology transfer agencies, vocational training organisations, business associations, finance institutions etc., which hold important competence to support regional innovation. (Asheim and Isaksen, 2002: 83) 
This definition stresses the fact that regional innovation systems are not only integrated through production and value chains (e.g. by supplier and buyer networks) but also by (formal) institutions and (informal) communities. The potential strengths of these systems consist in the capability to provide collective resources (cf. also Iammarino et al. in Chapter 7 for the regional embeddedness of MNCs especially in Germany and the UK). Examples of these regional collective goods are access to specialized technological knowledge, information about new markets, the vocational training of qualified and motivated manpower adapted to the needs of regional industry and also the stabilization of regional networks and patterns of cooperation between regional companies, schools, universities, technology transfer, R\&D facilities and political and administrative actors: 'Provision of such goods must be ensured by social or political arrangements, that is by forms of local governance' (Le Galès and Voelzkow, 2001: 1).

In conclusion, the regional embeddedness of companies is also based on institutions that may stabilize inter-organizational networks and contribute to the provision of 'local collective competition goods'. In contrast to the national level, these institutions are often closer to the specific companies, sectors and networks in the region, thus increasing the possibility of providing goods and services targeted to the specific needs of local companies. In addition, the territorial, social and often also technical proximity of regionally concentrated companies facilitates networks between suppliers, customers and competitors and the inter-organizational collaboration of heterogeneous actors, the exchange of personal information and contacts, and the specialization of companies at different phases of the same value chain. Often these regional institutions are more informal than the national ones; therefore they are designated as regional communities, milieus or cultures. These network-based, institutional and cultural dimensions of regional embeddedness may contribute to the regional agglomeration of companies (for the agglomeration of corporate HQ in Europe and the corresponding knowledge spillovers cf. Ahrweiler et al. and Koschatzky and Baier, Chapters 6 and 9 of this volume).

\subsection{THE EMBEDDEDNESS OF MULTINATIONAL COMPANIES}

The national and regional embeddedness of MNCs is an increasingly important topic in various streams of international business research (Heidenreich et al., 2012) because MNCs have to disembed their capabilities from their original context in order to transfer them to foreign subsidiaries (cf. Strambach and Klement, Chapter 8 in this volume). They 
can also use locally embedded competences in the corporate network. In the debate on the embeddedness of MNCs, the role of the societal context has been conceptualized in international business studies in basically three different ways: as the result of political decisions; as inter-organizational networks; or as institutions.

First, in transaction cost and internalization approaches, the context of MNCs is characterized by mainly politically induced market imperfections (Buckley and Casson, 1976). In the eclectic paradigm of international production, locational advantages of corporate sites are conceived as the result of immobile factors and non-transferable characteristics of national economies (cf. Dunning 1988, 1998). Examples of locational advantages are production factors such as labour, tariff and other trade barriers that induce companies to engage in foreign production. A foreign locality thus is basically analysed as a bundle of static and immobile assets that can be exploited by subsidiaries present in this country. In more recent versions of this paradigm, the focus has shifted to national institutions and cultural factors as belief systems and social capital, which are deemed to be crucial for the attractiveness of a country. However, also in this case locational advantages are conceived as the result of external, mostly political decisions (Dunning and Lundan, 2008: 138-9). The embeddedness of MNCs implied in classical approaches to international business is therefore conceptualized in a Polanyian way. National policies and market regulations, but also the inertia and territorial rootedness of social relations, constrain and shape the dynamics of market processes and corporate actors.

A second stream in international business studies analyses the MNC as a differentiated network of relatively autonomous subsidiaries with varying resources and capabilities (Ghoshal and Bartlett, 1990). This approach operationalizes the embeddedness of corporate subsidiaries and HQ through the relationship of these units to their suppliers, customers and competitors. The external networks in which the company is embedded shape the structures and strategies of the organization, especially 'the configuration of its organizational resources and the nature of interunit exchange relations that lead to such a configuration' (Ghoshal and Bartlett, 1990: 604).

On the basis of the network approach proposed by Ghoshal and Bartlett, a group of Swedish researchers have carefully analysed the role of these business networks in the technological competence of subsidiaries, their importance and their bargaining position within the MNC (Andersson et al., 2002, 2007; Forsgren et al., 2005; Holm et al., 2003 and Sölvell, Chapter 3 of this volume). They propose a concept of the embedded MNC for companies 'whose subsidiaries operate in business networks that, to a notable extent, are characterized by a high level of embeddedness among the relationship actors' (Forsgren et al., 2005: 97). Andersson et al. (2002) show that the 
business embeddedness of subsidiaries (i.e. the relations with customers and suppliers) and their technical embeddedness (i.e. the collaborative development of new products and processes, mostly with customers and suppliers) influence the performance of the subsidiary and its importance for the technological competence of the whole company: 'a high level of external embeddedness is positively related to the subsidiary's ability to provide expertise to the MNC', which in turn depends on the external embeddedness of the subsidiary (Andersson et al., 2007: 816). This research stream also develops the conceptual tools for analysing the systematic differences between the external embeddedness of subsidiaries in business networks and their internal embeddedness in the corporate context (Yamin and Andersson, 2011). Until now, however, regional, national or other proximities between the subsidiaries and their external partners have not been taken into account. The attention is exclusively focused on the role of external networks in the technological competences of MNCs and the relative influence of subsidiaries within the corporate network (Bouquet and Birkinshaw, 2008). The embeddedness argument implied in these network approaches to the MNC is therefore of a Granovetterian type: business relationships develop from arm's-length relationships to relatively stable, trust-based relations dependent on mutual adaptation and technological learning.

The institution-based view in international business studies has moved beyond these 'rationalist and functionalist concerns of efficiency and performance' (Clark and Geppert, 2011: 396). The basic assumption of this perspective is that formal and informal institutional rules shape organizational and individual behaviour (Peng and Khoury, 2008). The institutional embeddedness of a subsidiary in a particular business system influences the strategies of local subsidiaries (Geppert and Williams, 2006: 64). MNCs have to face not only pressures for efficiency, but also demands for national or regional legitimacy (cf. Westney and Zaheer, 2008: 356). However, MNCs do not operate in a homogeneous societal field characterized by unequivocal patterns of legitimacy and strong isomorphic pressures; they are embedded in heterogeneous national and regional business systems and cultures (cf. Sölvell, Chapter 3 of this volume). Especially the conditions in the country in which the headquarters are situated shape the configuration and control mechanisms as well as the globalization and innovation strategies of the whole company (cf. Geppert et al., 2003 for this home-country effect). Furthermore, the local transposition and adaptation of global corporate strategies is not only shaped by the strategic importance of the subsidiary in the corporate context, but also by its embeddedness in its institutional context and the legitimacy of the corporate strategy in the context of the host country: "National business systems ... provide local managers with different power resources, which support 
some strategies and politics while at the same time discouraging others' (Geppert and Williams, 2006: 54). MNCs are therefore confronted with conflicting isomorphic pressures and conflicting demands for legitimacy in their various national contexts (cf. Westney and Zaheer, 2008; Kostova et al., 2008; Meyer et al., 2011). In the globalization-localization framework of Bartlett and Ghoshal (1989) the conflicting aims of global integration and local adaptation give rise to a dilemma of institutionally embedded MNCs: '[T]he greater the degree of social embeddedness of the local subsidiary in a highly integrated business system, the more problematic the implementation of global practices' (Geppert and Williams, 2006: 63). Subsidiaries therefore should not only be externally embedded in heterogeneous national contexts, but also integrated in the corporate network in order to facilitate the corporate integration of heterogeneous capabilities (Meyer et al., 2011). ${ }^{2}$

In conclusion, for the analysis of MNCs and their subsidiaries, understanding their external context plays a major role because an $\mathrm{MNC}$ is by definition a cross-border organization embedded in different national contexts. In addition, the external context is a major or even the most important source of innovativeness. In different streams of the international business literature these national contexts are conceived in different ways. Studies highlight either the political embeddedness, the embeddedness in inter-organizational networks or the institutional embeddedness of MNCs: (1) in transaction cost and internalization approaches the context of MNCs is analysed as the result of (mostly) political regulations of economic processes (Buckley and Casson, 1976; Dunning, 1988); (2) in approaches that conceive MNCs as differentiated networks (Ghoshal and Bartlett, 1990) corporate environments are in general conceptualized as 'business networks' (Andersson et al., 2007; Forsgren et al., 2005), and these approaches focus on the patterns of exchange and cooperation between companies and their suppliers, customers and sometimes also competitors; (3) institutional approaches focus on the influence of (mostly) national business systems and the corresponding norms, values and rationalities. Formal and informal rules in different national environments shape the interpretations, strategies and norms that regulate the behaviour of individuals and collective actors (Geppert and Williams, 2006; Peng and Khoury, 2008). The environments of MNCs are thus characterized by (politically induced) market imperfections, networks and institutions.

These three forms of embeddedness reflect different facets of the dilemma between globalization and localization that are constitutive for MNCs (cf. Sölvell, Chapter 3 in this volume). MNCs are confronted with the contradictory challenges of territorially unbound economic logics and challenges and politically regulated national markets. They have to decide 
how to combine global marketing and procurement strategies with the advantages of specific business networks (Mattes, 2010). They are also confronted with the contradictory and conflictual demands of companywide control and coordination mechanisms (which are often shaped by the home-country context of the corporation) and the interests and coordination patterns of locally embedded subsidiaries.

\subsection{THE EMBEDDEDNESS OF MNCs: TOWARDS AN INTEGRATED PERSPECTIVE}

We began with the observation that the competitive advantage of MNCs under worldwide competition also depends on the cross-border utilization of regional and national capabilities. Not only the organizational coordination of internationally distributed innovation processes but also the capability of a company to tap into regional and national contexts is crucial for the innovativeness of a company. While the internationalization of a company facilitates cross-border processes of learning, its regional and national embeddedness fosters the exploitation of sticky, tacit knowledge (cf. Bathelt et al., 2004 for the role of local buzz and global pipelines in interactive learning). This introductory chapter has discussed the possibilities and challenges of exploiting territorially embedded competences and of combining them with inner-organizational learning processes in MNCs from four different angles.

First, a major assumption of the embeddedness concept is that companies orientate themselves towards established practices, routines, taken-for-granted accounts and formal rules of their societal context in order to reduce the uncertainties that emerge from instable and unpredictable organizational environments and to solve the coordination problems arising between heterogeneous actors. The two 'founding fathers' of the embeddedness debate have proposed two complementary, either structural or relational, conceptualizations. The Polanyian and the Granovetterian versions of the embeddedness concept can be used for specifying the duality of national and regional institutions and corporate actors in a dynamic and recursive way. An initial insight of the previously summarized debates is thus that the relationships between companies and their environment cannot be reduced to a unilateral determination or to isomorphic pressures. Companies use specific assets of their environment and choose to adapt or not to adapt to specific institutional constraints and opportunities, just as institutions take into account economic and organizational challenges. Companies and institutions therefore adapt to each other and affect each other's evolution ('co-evolution'). 
Second, we briefly summarized the debates on the (mostly formal) national institutions that shape corporate strategies and structures. Of particular importance are the relations of companies with their employees, customers, clients, owners and banks and their relation to schools, training facilities, universities and research institutes. The concept of 'institutional complementarities' refers to the fact that the institutional patterns in these fields are not isolated but are closely related and that the (mostly national) patterns of economic governance, labour relations, social and innovation policies, education and training are mutually interdependent and stabilize each other. This concept runs the risk of underestimating the tensions between different institutional logics, the conflicts between different actors, supranational learning processes and incremental change, but it rightly stresses the relative coherence, the relative closure and also the relative stability, especially of national institutional orders.

Another insight of this debate is that institutions contribute towards solving organizational coordination problems with economic and noneconomic actors; they facilitate interactive learning and provide collective goods and resources.

Third, we referred to debates on the regional embeddedness of economic processes and especially of MNCs. We highlighted the role of (formal as well as informal, i.e. cultural) regional institutions and of inter-organizational networks in the provision of resources and the ways in which companies deal with uncertainties and coordination problems. Basically this is also true at the national level. Regional institutions, however, are often more focused on the specificities of regional companies and therefore can provide products, services and qualifications targeted more directly at the specific requirements of the local industry. In addition, the organizational, institutional and cognitive proximity of regionally agglomerated companies and actors facilitate interactive learning (Mattes, 2011). Therefore the regional level is especially important for the innovativeness of subsidiaries (cf. the contributions of Heidenreich and Mattes, Asheim et al., Cooke, Iammarino et al., Koschatzky and Baier, and Barmeyer and Krüth, Chapter 11 in this volume).

Finally, we identified three dimensions of corporate embeddedness: market failures due to political decisions and immobile production factors; business networks; and institutions. MNCs and their HQ are thus socially embedded as the result of political decisions and restrictions, by business networks with their suppliers, customers and competitors, and by formal and informal institutions. However, these forms of embeddedness potentially contradict a corporate strategy aimed at the global integration of subsidiaries from different countries and thus has to disregard national and regional particularities. Therefore the general dilemma between 


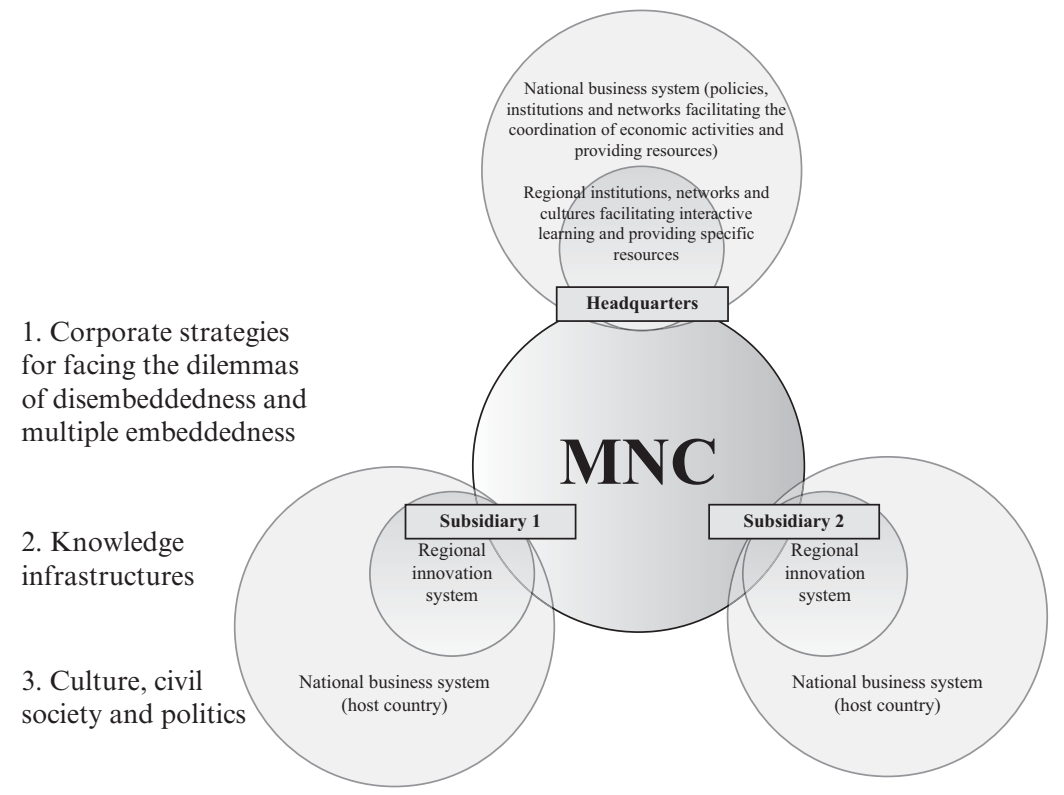

Figure 1.1 Multinational companies and the dilemma between multiple embeddedness and disembeddedness

globalization and localization that is characteristic for MNCs is also transformed into a dilemma between embeddedness and disembeddedness and the respective advantages and risks. Therefore it can be assumed that MNCs use selectively and strategically the advantages of embedded and disembedded production and innovation strategies. In addition, MNCs are not only embedded in a single national or regional context, but have to take into account the institutional contexts in different home and host countries ('multiple embeddedness').

The basic insights of this discussion can be condensed as follows. Corporate embeddedness has to take into account the co-evolution of institutions and organizations, the role of institutional complementarities especially at the national level, the contribution of institutions to the solution of coordination problems, the political, institutional, cultural and network-based embeddedness of MNCs and their subsidiaries at the national and the regional level, multiple embeddedness and the dilemma between embeddedness and disembeddedness. These six insights are summarized in part in Figure 1.1, illustrating the co-evolution of multiply embedded MNCs and their national and regional contexts (policies, institutions, cultures and networks) as well as the related dilemmas. 
Figure 1.1 also serves as a general framework for the three topics discussed by the following contributions in this volume: (1) the varieties of corporate strategies facing the dilemmas of embeddedness and disembeddedness; (2) the role of national and regional knowledge infrastructures in corporate embeddedness; and (3) the role of culture, business associations and politics in the embeddedness of multinationals.

\subsection{OVERVIEW OF CONTRIBUTIONS TO THIS VOLUME}

The structure of this volume reflects the aim of integrating contributions mostly from regional studies and international business studies on the strategies and varieties of corporate embeddedness. In these contributions three of the most important topics as previously mentioned are discussed in detail: (1) the dilemma of globalization and localization and the corresponding types of knowledge and corporate embeddedness; (2) the essential role of the national and regional knowledge infrastructure (companies, interorganizational networks, knowledge-based services, regional scientists and $\mathrm{R} \& \mathrm{D}$ institutions) in embedded learning and innovation processes; and (3) the cultural and political construction of corporate embeddedness.

The innovativeness of MNCs is based both on the complementary use of international but inner-organizational networks between headquarters and subsidiaries as well as on the advantages of external, for example regional, linkages. Internal and external networks and learning processes, however, are fundamentally different. In their chapter, Martin Heidenreich and Jannika Mattes analyse the different dimensions, the challenges and the risks of regional embeddedness on the basis of international business and regional studies. The authors theorize that regional institutions can bridge the gap between inner-organizational and regional logics and networks by informal norms and rules based on proximity, by formal institutions stabilizing regional patterns of interaction and cooperation, and by the provision of resources for knowledge generation and diffusion that contribute to the emergence and stabilization of regional networks. However, strong forms of regional embedding are not always the best option for the involved companies. Also, for regional industrial policies, a specific focus on MNCs may be risky. On the basis of four regional and organizational case studies, the authors derive four different types of regional embeddedness as the combined result of corporate and regional strategies, showing that each constellation brings its own chances and challenges. In any case, regional embeddedness remains a highly challenging strategic option for subsidiaries as well as for other regional actors. 
The chapter by Örjan Sölvell on multi-home-based corporations effectively links the debates on clusters and MNCs by analysing the choice between globalization and localization strategies as the dilemma between 'insiderization' and 'outsiderization'. While insiders in a cluster can tap locally bound capabilities and gain access to local networks but require a certain autonomy within the corporate network, outsiders can benefit from the advantages of global coordination and can exploit globally available capabilities, technologies and opportunities: 'Global markets are central for MNCs' cost position, while insider positions in clusters are central for their innovation processes'. Multi-domestic and transnational corporations exploit either the insider or the outsider advantages. By co-locating divisional $\mathrm{HQ}, \mathrm{R} \& \mathrm{D}$ and design functions in multiple home bases, the multi-home-based corporation (MHC) attempts to mitigate 'the dilemma of increased insiderization in host clusters, leading to increased outsiderization of subsidiary units within the overall MNC'.

Bjørn T. Asheim, Bernd Ebersberger and Sverre J. Herstad analyse in their contribution how the specific type of organizational knowledge affects embeddedness in national and international innovation networks. They distinguish between analytical (scientific, deductive) and synthetic (experience-based, inductive) knowledge and, on the basis of the Norwegian community innovation survey (2005), test whether a synthetic knowledge base is more sensitive to proximity effects, co-localization and embeddedness than an analytical knowledge base, which should facilitate integration in global innovation networks. They show that an analytical knowledge base and MNC affiliation increase the geographical scope: the companies are less dependent on co-location and physical presence. In the case of a synthetic knowledge base, the presence of an affiliate in a specific region increases the likelihood of external collaboration in this region. International collaborative linkages are also less geographically dispersed.

In his chapter on the 'varieties of innovative impulse', Philip Cooke analyses the interaction between MNCs and smaller enterprises. He distinguishes two basic forms of relationships between regions and MNCs that he confronts in terms of a Porterian and a Jacobian perspective. In the first case innovation and competitiveness are the result of regional specialization. In the second case, which draws on the pattern ascribed to J. Jacobs, competitive advantage is also the result of diversification, regional variety of knowledge spillovers and 'transversality' thinking. The advantages of 'Jacobian' embedded skills, that is, especially the 'related variety' of regions, is a key motivation for the regional embeddedness of MNCs. Taking the example of four different Swedish clusters, the author describes three different types of regional embeddedness of MNCs among SME clusters: (1) single MNC-dominated clusters; (2) platforms in which 
MNCs and specialist knowledge suppliers collaborate around their quest for 'related variety'; and (3) science excellence. In the next step these three types of MNC embeddedness are generalized on the basis of additional empirical evidence. The first type, which the author terms 'integrated supply chain model' (ISC), is characterized by a focal company that coordinates proximate suppliers of different inputs. The second type, the 'advanced aggregator model' (AA), is characterized by regionally embedded skills and 'systems integration' potential. The 'science excellence model' (SE) is typical of regions with high knowledge intensity and institutional innovation. The author concludes that distributed knowledge flows, related variety and regional transversality are cornerstones of the future innovation-centred economy.

Petra Ahrweiler, Michel Schilperoord, Nigel Gilbert and Andreas Pyka analyse the embeddedness of MNCs in innovation networks and the results of their involvement in collaborative R\&D. They take the example of Ireland, a country that relies heavily on foreign-owned MNCs and their R\&D, thus rendering involvement in innovation networks and cooperative research crucial for national innovativeness. Given the nonlinear and complex dynamics of knowledge spillover effects, this requires complex assumptions on the technological capital ('kenes') of the firms, on market dynamics, on organizational learning, on partnerships and knowledge transfer, on networks and start-ups. Given the necessarily complex assumptions that the authors explain with reference to the respective literature, they use an agent-based simulation, that is, 'a theory running on a computer'. MNCs are modelled as larger companies. It can be shown that they have a beneficial effect on the capital and knowledge level of the economy. If they cooperate with their environment, this will raise the knowledge level and the stability of the whole economy. This shows not only the role of corporate embeddedness in a national system of innovation, but also the potential of agent-based modelling for a dynamic and detailed description of a complex system.

On the basis of in-depth interviews in German and British MNCs, Simona Iammarino, Jan-Philipp Kramer, Elisabetta Marinelli and Javier Revilla Diez analyse three different dimensions of the regional embeddedness of these companies: the interdependence of regional and organizational knowledge creation; the influence of the regional environment on corporate R\&D strategies; and the types of industrial and scientific patterns of cooperation between the subsidiaries and other companies within and beyond the group. The authors show that MNCs 'make use of and provide skills to the local labour market [and] benefit from the presence of regional universities and research infrastructure'. Regional partners, especially in higher education, the regional availability of scientists and $R \& D$ 
resources as well as regional cluster and network initiatives significantly influence the regional embeddedness of MNCs. Decentralized development activities facilitate their interaction with the environment. In general, German companies and employees are more regionally embedded than their UK counterparts.

The chapter by Simone Strambach and Benjamin Klement discusses the organizational decomposition of innovation processes, especially in the German software industry. It focuses on the knowledge interactions between different subsidiaries of an $\mathrm{MNC}$ and between subsidiaries and external companies, universities, research institutes, customers and knowledge-based business services. As a function of the available methods for decontextualizing the software production from the environment in which the software will be used, the authors distinguish between customized solution providers, cost-driven outsourcing firms and complex innovation process managers, highlighting the multi-local and multi-scalar character of organizationally decomposed innovation processes. On the one hand, the internationalization of software production in non-OECD countries is especially difficult in the software industry because the difficulties of separating knowledge-creating and knowledge-using activities limit the delegation of knowledge-creating activities to offshore partners. On the other hand, in cases where parts of the innovation process are outsourced, this significantly raises the levels of competences and the autonomy of the external subsidiaries. These subsidiaries establish their own linkages to their regional environment, for example to public and private knowledge-based services or research institutes. This shows that the degree of regional embeddedness is also linked to increased autonomy and advanced technological capabilities of the subsidiary.

The chapter by Knut Koschatzky and Elisabeth Baier asks whether European MNCs are equally spread over the European territory independently of regional endowment with knowledge resources or whether they are concentrated in innovative locations where they can exploit localized, context-specific knowledge in regional networks. Using European regional data supplemented by the locations of 700 research-oriented MNC HQ, the authors identify four clusters of economic regions in Europe (hubs of knowledge generation and innovation, lagging regions, public and service driven innovation centres and industry-driven innovation centres). MNCs prefer the first type as the location for their corporate headquarters. Therefore the hypothesis of an equal distribution that could be expected for footloose companies can be refuted: geography, and therefore the possibility of regional embeddedness, also matters for corporate headquarters.

Taking the example of seven European regions, Dieter Rehfeld observes a shift from 'spontaneous' to 'constructed' regional embeddedness for 
which the activities of foundations and social networks are also important. He analyses regional embeddedness according to four dimensions: human resources is the most important dimension of regional embeddedness, followed by innovation and quality of life, with finally sustainability playing only a minor role. He shows that bigger companies and those that are founded in the region are more regionally embedded than smaller and medium-sized companies and those with foreign origins. Similar to the results of Asheim et al., Rehfeld also shows that IT companies and financial and business services are less involved in the region than other companies. Four motives are crucial for the decision to rely on regional embeddedness: taking part in an innovative business milieu; making use of the local market; strengthening regional attractiveness; and building up social capital.

The chapter by Christoph Barmeyer and Katharina Krüth on the pôles de compétitivité (competitiveness clusters) analyses France's experience with cluster policies as an indicator of a fundamental transformation of the previous, centralized French governance model, characterized by a status-based logic and segmented social networks. They expect a shift from 'centralized and top-down mechanisms of political coordination by the state towards decentralized structures in terms of innovation policy [and from] personalized and homogeneous social networks as the basis of cooperative innovation activities towards multiple and heterogeneous cooperation structures' see p. 272 in this volume). On the basis of three case studies, the authors are able to demonstrate how bottom-up and top-down tendencies are combined and how heterogeneous partners cooperate, thus demonstrating a transformation of the previous Colbertist model of economic governance.

In his chapter, Bob Hancké discusses the origins of business coordination, a theoretical gap of the varieties of capitalism approach. Taking the example of Central and Eastern Europe, he analyses the emergence of interfirm coordination in the engineering sector. A specific feature of these countries is the important role of large foreign MNCs that have to cope with bottlenecks in the production of collective goods such as skills and regional technological capacity. In the process of rapid reindustrialization, which to a large extent was led and organized in these countries by MNCs, skills shortages and technical bottlenecks of suppliers led to collective action problems. This has forced these companies to build forms of interfirm coordination, often supported by international chambers of commerce that had the ability to enforce compliance with collective solutions to training bottlenecks. Therefore, even without public interventions, 'endogenous' forms of business coordination have emerged, because only in this way could the cooperation between MNCs faced with local bottlenecks be enforced. This shows that, even without historical precursors and under highly unlikely conditions, islands of institutionally 
embedded production can emerge in an open, co-evolutionary process, which in this case is driven by local subsidiaries of global companies.

Rajneesh Narula and José Guimón draw several political conclusions about the debate on corporate embeddedness. They begin with the observation that foreign direct investments by MNCs might play an ambivalent role in national innovation systems: they contribute either to the upgrading of domestic clusters or to the reduction of its long-run potential (e.g. by the 'crowding out' of innovative domestic firms or the downgrading of a foreign subsidiary's R\&D mandate). The role of MNCs in the upgrading of national innovation systems also depends on the level of domestic innovative capacities. Only when these local competences are sufficiently developed can regions profit from the competences of foreign MNCs by integrating them in local clusters. This observation is especially important for the new member states of the EU, as the role of foreign subsidiaries in these countries is significantly higher than in the Western and Southern European countries. The authors conclude that innovation policies in the new member states should focus mostly on the embeddedness and upward evolution of existing MNC operations by creating linkages between the MNC subsidiary and local organizations and clusters. These countries should try to attract 'demand-driven' rather than 'supply-driven' R\&D. Similar to Hancké (Chapter 12), they conclude that in this context the upgrading of human capital and public R\&D are especially important. The concluding chapter by Jannika Mattes and Martin Heidenreich draws together some of the ideas presented in the previous chapters in order to systemize the dilemmas of corporate embeddedness, the role of external knowledge structures and the influence of strategic actions of policy makers and corporate actors.

Together, the 14 contributions in this volume suggest that national and regional embeddedness can be an important asset for augmenting the innovativeness and competitiveness of MNCs and their subsidiaries as well as the economic position of their home and host countries. However, corporate and regional embedding strategies first have to take into account the dilemmas that go along with such a strategy: lock-in effects, stronger subsidiaries and thus difficulties of integrating them in a global strategy (Part I). Second, the innovativeness of subsidiaries depends on the respective knowledge infrastructures, that is, on universities and $\mathrm{R} \& \mathrm{D}$ facilities as well as on the advanced technological and business competences of knowledge-based service providers and regionally concentrated corporate headquarters (Part II). Third, corporate embeddedness is becoming less and less a stable cultural feature of national and regional innovation systems and increasingly the result of entrepreneurial strategies and political decisions (Part III). These results show that research on 
the institutional embeddedness of MNCs can provide a basis for fruitful interchange among scholars interested in economic sociology, regional studies, national production and innovation models, and international management.

\section{NOTES}

1. Boyer (2005: 67) defines the 'complementarity of institutional forms (as) a configuration in which the viability of an institutional form is strongly or entirely conditioned by the existence of several other institutional forms, in such a manner that their conjunction offers greater resilience and possibly better performance compared to alternative configurations'.

2. This internal embeddedness of subsidiaries in the corporation is disregarded in this book because its conceptual inclusion would overstretch the embeddedness concept. The corresponding challenges are better analysed by conventional organizational sociological concepts such as integration and coordination.

\section{REFERENCES}

Andersson, U., Forsgren, M. and Holm, U. (2002), 'The strategic impact of external networks: subsidiary performance and competence development in the multinational corporation', Strategic Management Journal, 23 (11): 979-96.

Andersson, U., Forsgren, M. and Holm, U. (2007), 'Balancing subsidiary influence in the federative MNC. A business network view', Journal of International Business Studies, 38 (5): 802-18.

Asheim, B. and Isaksen, A. (2002), 'Regional innovation systems: the integration of local "sticky" and global "ubiquitous" knowledge', Journal of Technology Transfer, 27 (1): 77-86.

Bartlett, C.A. and Ghoshal, S. (1989), Managing Across Borders: The Transnational Solution, Boston, MA: Harvard Business School Press.

Bathelt, H., Malmberg, A. and Maskell, P. (2004), 'Clusters and knowledge: local buzz, global pipelines and the process of knowledge creation', Progress in Human Geography, 28 (1): 31-56.

Beckert, J. (2003), 'Economic sociology and embeddedness: how shall we conceptualize economic action?', Journal of Economic Issues, 37 (3): 769-87.

Boschma, R.A. (2005), 'Proximity and innovation: a critical assessment', Regional Studies, 39 (1): 61-74.

Bouquet, C. and Birkinshaw, J. (2008), 'Managing power in the multinational corporation: how low-power actors gain influence', Journal of Management, 34 (3): 477-508.

Boyer, R. (2005), 'Coherence, diversity, and the evolution of capitalisms. The institutional complementarity hypothesis', Evolutionary and Institutional Economics Review, 2 (1): 43-80.

Buckley, P.J. and Casson, M. (1976), The Future of the Multinational Enterprise, London: Macmillan.

Cantwell, J., Dunning, J.H. and Lundan, S.M. (2010), 'An evolutionary approach 
to understanding international business activity: the co-evolution of MNEs and the institutional environment', Journal of International Business Studies, 41 (4): 567-86.

Clark, E. and Geppert, M. (2011), 'Subsidiary integration as identity construction and institution building: a political sensemaking approach', Journal of Management Studies, 48 (2): 395-416.

Cooke, P., Asheim, B.T. and Boschma R. (eds) (2011), Handbook of Regional Innovation and Growth, Cheltenham, UK and Northampton, MA, USA: Edward Elgar.

Cooke, P., Heidenreich, M. and Braczyk, H.-J. (2004), Regional Innovation Systems (2nd edn), London; New York: Routledge.

Dunning, J.H. (1988), 'Toward an eclectic theory of international production: a restatement and some possible extensions', Journal of International Business Studies, 19 (1): 1-31.

Dunning, J.H. (1998), 'Location and the multinational enterprise: a neglected factor?', Journal of International Business Studies, 29 (1): 45-66.

Dunning, J.H. and Lundan, S.M. (2008), Multinational Enterprises and the Global Economy (2nd edn), Cheltenham, UK and Northampton, MA, USA: Edward Elgar.

Edquist, C. (2005), 'Systems of innovation - perspectives and challenges', in J. Fagerberg, D.C. Mowery and R.R. Nelson (eds), The Oxford Handbook of Innovation, Oxford: Oxford University Press, pp. 181-208.

Fligstein, N. (2001), 'Social skill and the theory of fields', Sociological Theory, 19 (2): 105-25.

Forsgren, M., Holm, U. and Johanson, J. (2005), Managing the Embedded Multinational. A Business Network View, Cheltenham, UK and Northampton, MA, USA: Edward Elgar.

Geppert, M. and Williams, K. (2006), 'Global, national and local practices in multinational corporations: towards a sociopolitical framework', International Journal of Human Resource Management, 17 (1): 49-69.

Geppert, M., Williams, K. and Matten, D. (2003), 'The social construction of contextual rationalities in MNCs: an Anglo-German comparison of subsidiary choice', Journal of Management Studies, 40 (3): 617-41.

Ghoshal, S. and Bartlett, C.A. (1990), 'The multinational corporation as an interorganizational network', Academy of Management Review, 15: 603-25.

Giddens, A.(1990), The Consequences of Modernity, Cambridge/Oxford:Polity Press.

Grabher, G. (1993), 'Rediscovering the social in the economics of interfirm relations', in G. Grabher (ed.), The Embedded Firm. On the Socioeconomics of Industrial Networks, London and New York: Routledge, pp. 1-31.

Granovetter, M. (1985), 'Economic action and social structure: the problem of embeddedness', American Journal of Sociology, 91 (3): 481-510.

Hall, P.A. and Gingerich, D.W. (2009), 'Varieties of capitalism and institutional complementarities in the political economy: an empirical analysis', British Journal of Political Science, 39 (3): 449-82.

Hall, P.A. and Soskice, D. (2001), 'An introduction to varieties of capitalism', in P.A. Hall and D. Soskice (eds), Varieties of Capitalism: The Institutional Foundations of Comparative Advantage, Oxford: Oxford University Press, pp. 1-68.

Hancké, B., Rhodes, M. and Thatcher, M. (eds) (2007), Beyond Varieties of Capitalism: Conflict, Contradiction, and Complementarities in the European Economy, Oxford: Oxford University Press. 
Heidenreich, M., Barmeyer, C. and Koschatzky, K. (2010), 'Product development in multinational companies', in P. Ahrweiler (ed.), Innovation in Complex Systems, London: Routledge, pp. 137-49.

Heidenreich, M., Barmeyer, Ch., Koschatzky, K., Mattes, J., Baier, E. and Krüth, K. (2012), Multinational Enterprises and Innovation: Regional Learning in Networks, London: Routledge.

Held, D., McGrew, A., Goldblatt, D. and Perraton, J. (1999), Global Transformations, Cambridge: Polity Press.

Hollingsworth, J.R. and Boyer, R. (1997), 'Coordination of economic actors and social systems of production', in J.R. Hollingsworth and R. Boyer (eds), Contemporary Capitalism: The Embeddedness of Institutions, Cambridge, UK: Cambridge University Press, pp. 1-47.

Holm, U., Malmberg, A. and Sölvell, Ö. (2003), 'Subsidiary impact on hostcountry economies. The case of foreign-owned subsidiaries attracting investment into Sweden', Journal of Economic Geography, 3: 389-408.

Kostova, T., Roth, K. and Dacin, M.T. (2008), 'Institutional theory in the study of multinational corporations: a critique and new directions', Academy of Management Review, 33: 994-1006.

Krippner, G.R. and Alvarez, A.S. (2007), 'Embeddedness and the intellectual projects of economic sociology', Annual Review of Sociology, 33: 219-40.

Krugman, P. (1991), Geography and Trade, Cambridge, MA: MIT Press.

Le Galès, P. and Voelzkow, H. (2001), 'Introduction: the governance of local economies', in C. Crouch, P. Le Galès, C. Trigilia and H. Voelzkow, Local Production Systems in Europe. Rise or Demise?, Oxford: Oxford University Press, pp. 1-24.

Lundvall, B.-Å. (1992), 'Introduction', in B.-Å. Lundvall (ed.), National Systems of Innovation: Towards a Theory of Innovation and Interactive Learning, London: Pinter, pp. 1-19.

Marshall, A. (1982), Principles of Economics, 9th edn, London: Macmillan (first edn 1890).

Mattes, J. (2010), Innovation in Multinational Companies: Organisational, International and Regional Dilemmas, Bern et al.: Peter Lang.

Mattes, J. (2011), 'Dimensions of proximity and knowledge bases: innovation between spatial and non-spatial factors', Regional Studies (forthcoming), DOI: 10.1080/00343404.2011.552493.

Maurice, M., Sellier, F. and Silvestre, J.-J. (1986), The Social Foundations of Industrial Power. A Comparison of France and Germany, Cambridge, MA and London: MIT Press.

Metcalfe, S. (1995), 'The economic foundations of technology policy: equilibrium and evolutionary perspectives', in P. Stoneman (ed.), Handbook of the Economics of Innovation and Technological Change, Oxford: Blackwell, pp. 409-512.

Meyer, K.E., Mudambi, R. and Narula, R. (2011), 'Multinational enterprises and local contexts: the opportunities and challenges of multiple embeddedness', Journal of Management Studies, 48 (2): 235-52.

Nelson, R.R. (1994), 'The co-evolution of technology, industrial structure, and supporting institutions', Industrial and Corporate Change, 3 (1): 47-63.

North, D.C. (1991), 'Institutions', Journal of Economic Perspectives, 3 (1): 97-112.

Ohmae, K. (1990), The Borderless World: Management Lessons in the New Logic of the Global Market Place, New York: Harper.

Patel, P. and Pavitt, K. (1991), 'Large firms in the production of the world's 
technology: an important case of "Non-Globalisation"”, Journal of International Business Studies, 22 (1): 1-21.

Peng, M.W. and Khoury, T.A. (2008), 'Unbundling the institution-based view of international business strategy', in A.M. Rugman (ed.), The Oxford Handbook of International Business, Oxford: Oxford University Press, pp. 256-68.

Phene, A. and Almeida, P. (2008), 'Innovation in multinational subsidiaries: the role of knowledge assimilation and subsidiary capabilities', Journal of International Business Studies, 39 (5): 901-19.

Piore, M.J. and Sabel, C.F. (1984), The Second Industrial Divide. Possibilities for Prosperity, New York: Basic Books.

Polanyi, K. (1944), The Great Transformation, New York: Holt, Rinehart.

Porter, M.E. (1998), 'Clusters and the new economics of competition', Harvard Business Review, November/December, 77-90.

Sölvell, Ö. and Birkinshaw, J. (2007), 'Multinational enterprises and the knowledge economy: leveraging global practices', in J.H. Dunning (ed.), Regions, Globalization, and Knowledge-based Economy, repr. Oxford: Oxford University Press, pp. 82-105.

Storper, M. (1997), The Regional World: Territorial Development in a Global Economy, New York and London: Guilford Press.

Streeck, W. (1991), 'On the social and political conditions of diversified quality production', in E. Matzner and W. Streeck (eds), Beyond Keynesianism: The Socio-Economics of Production and Full Employment, Aldershot, UK and Brookfield, US: Edward Elgar, pp.21-61.

Sturgeon, T.J. (2002), 'Modular production networks: a new American model of industrial organization', Industrial and Corporate Change, 11 (3): 451-96.

Westney, E. and Zaheer, S. (2008), 'The multinational enterprise as an organization', in A.M. Rugman (ed.), The Oxford Handbook of International Business, Oxford: Oxford University Press, pp. 341-66.

Whitley, R. (1999), Divergent Capitalisms: The Social Structuring and Change of Business Systems, Oxford: Oxford University Press.

Whitley, R. (2002), 'Multiple market economies' in D. Sachsenmaier, J. Riedel and S.N. Eisenstadt (eds), Reflections on Multiple Modernities, Leiden, Boston and Köln: Brill, pp. 217-40.

Womack, J.P., Jones, D.T. and Roos, D. (1990), The Machine That Changed the World, New York: Rawson.

Yamin, M. and Andersson, U. (2011), 'Subsidiary importance in the MNC: what role does internal embeddedness play?', Journal of Management Studies, 20 (2): $151-62$.

Zeitlin, J. (2008), 'The rediscovery of industrial districts: a disciplinary paradox', in G. Jones and J. Zeitlin (eds), The Oxford Handbook of Business History, Oxford. Oxford University Press, pp. 219-41. 